\title{
Structure, Functional Expression, and Cerebral Localization of the Levocabastine-Sensitive Neurotensin/Neuromedin N Receptor from Mouse Brain
}

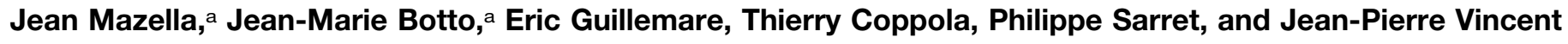 \\ Institut de Pharmacologie Moléculaire et Cellulaire, Unité Propre de Recherche 411, Centre National de la Recherche \\ Scientifique, 06560 Valbonne, France
}

\begin{abstract}
This work describes the cloning and expression of the levocabastine-sensitive neurotensin (NT) receptor from mouse brain. The receptor protein comprises 417 amino acids and bears the characteristics of G-protein-coupled receptors. This new NT receptor (NTR) type is $39 \%$ homologous to, but pharmacologically distinct from, the only other NTR cloned to date from the rat brain and the human HT29 cell line. When the receptor is expressed in Xenopus laevis oocytes, the $\mathrm{H} 1$ antihistaminic drug levocabastine, like NT and neuromedin N, trig-
\end{abstract}

gers an inward current. The pharmacological properties of this receptor correspond to those of the low-affinity, levocabastinesensitive NT binding site described initially in membranes prepared from rat and mouse brain. It is expressed maximally in the cerebellum, hippocampus, piriform cortex, and neocortex of adult mouse brain.

Key words: neurotensin; neuromedin N; receptor; levocabastine; cloning; low affinity; G-protein-coupled
The existence of multiple receptors for the neurotensin (NT)related peptides was suggested initially by the description of two families of NT binding sites ( $\left.K_{\mathrm{D} 1}=0.17 \mathrm{nM} ; K_{\mathrm{D} 2}=2 \mathrm{nM}\right)$ in rat brain synaptic membranes (Mazella et al., 1983) and by the ability of the antihistaminic H1 drug levocabastine to totally inhibit NT binding to the low-affinity sites without affecting binding to the high-affinity sites (Schotte et al., 1986). The functional properties of NT receptors (NTRs) are numerous and include stimulations of intracellular cGMP production, turnover of inositol phosphates and $\mathrm{Ca}^{2+}$ release, and inhibition of cAMP accumulation (for review, see Vincent, 1995). NT also produces several central and peripheral effects. For example, central administration of NT induces hypothermia and analgesia as well as an increase in dopamine turnover and release (for review, see Vincent, 1995).

Recently, an NTR cloned from rat brain (Tanaka et al., 1990) and from the human colon carcinoma HT29 cell line (Vita et al., 1993) was identified as being the high-affinity NT binding site insensitive to levocabastine (NTRH). This NTR was stably transfected in eukaryotic cells and was functionally coupled to phospholipase $\mathrm{C}$ and $\mathrm{Ca}^{2+}$ mobilization (Hermans et al., 1992, Watson et al., 1992, Chabry et al., 1994). More recently, the development of a nonpeptide NT antagonist, SR48692, exhibiting a high affinity for NTRH (Gully et al., 1993), demonstrated that this receptor type was involved in the dopamine-releasing effect of NT in

Received March 13, 1996; revised June 14, 1996; accepted June 27, 1996.

This work was supported by Centre National de la Recherche Scientifique. We thank Dr. Jean-Philippe Hugnot, Gisèle Jarretou, and Gilles Toumaniantz for fruitful discussion and technical comments. We also thank Franck Aguila for excellent artwork, Nicole Zsürger for her help in histology, and Dr. Patrick Kitabgi for carefully reading this manuscript.

GenBank accession number for the nucleotidic sequence of mouse NTRL: U51908.

Correspondence should be addressed to Jean Mazella, Institut de Pharmacologie Moléculaire et Cellulaire, Unité Propre de Recherche 411, Centre National de la Recherche Scientifique, 660 Route des Lucioles, Sophia Antipolis, 06560 Valbonne, France.

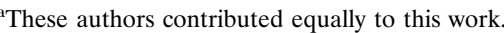

Copyright (C) 1996 Society for Neuroscience $0270-6474 / 96 / 165613-08 \$ 05.00 / 0$ guinea pig striatal slices and in the turning behavior induced by unilateral intrastriatal injection of NT in the mouse (Gully et al., 1993). SR48692, however, failed to antagonize NT-induced hypothermia and analgesia in the mouse and rat (Dubuc et al., 1994), suggesting the existence of other types of NT receptors. Since the cloning of the rat brain NTRH (Tanaka et al., 1990) and of its equivalent in the human HT29 cell line (Vita et al., 1993), no other NT receptor type has been identified.

We describe in this work the cloning and functional expression of the low-affinity levocabastine-sensitive NT receptor (NTRL). This receptor is poorly recognized by the nonpeptide NT antagonist SR48692. Its tissue distribution and ontogenic expression were analyzed and compared with those of the previously cloned NTRH.

\section{MATERIALS AND METHODS}

Materials. NT and neuromedin N (NN) were purchased from Peninsula Laboratories (Belmont, CA). DTrp ${ }^{11}$-NT, Trp ${ }^{11}-\mathrm{NT}$, and xenin were from Bachem (Torrance, CA). SR48692 was from Sanofi. Levocabastine was a generous gift from Dr. Alain Schotte (Janssen Pharmaceutica, Beerse, Belgium). NT was iodinated and purified as described previously (Sadoul et al., 1984). The pcDNA3 expression vector was purchased from Invitrogen (San Diego, CA), DMEM and gentamycin from Life Technologies (Gaithersburg, MD), fetal calf serum from Boehringer Mannheim (Boehringer, Indianapolis, IN), and restriction endonucleases from Eurogentec.

cDNA cloning and expression of the mouse NTR. A cDNA library was constructed from mouse brain poly $\left(\mathrm{A}^{+}\right) \mathrm{RNA}$ into the UniZap XR vector (Stratagene, LaJolla, CA) according to the procedures described by the manufacturer. Clones $\left(5 \times 10^{5}\right)$ derived from the cDNA library were screened by hybridization with the total open reading frame of the rat NTR cDNA $(1.27 \mathrm{~kb})$ (Tanaka et al., 1990). Hybridization and filter washing were carried out at $60^{\circ} \mathrm{C}$ under previously described conditions (Sambrook et al., 1989). One hybridization-positive clone was isolated by repeated purification. Nucleotide sequences were determined in both strands by using the Abi-prime DNA sequencing kit (Applied Biosystems, Foster City, CA).

The $1.6 \mathrm{~kb}$ EcoRI-ApaI fragment of the NTRL was inserted into a eukaryotic expression vector (pcDNA3) containing the cytomegalovirus promoter and the resistance to G418 gene as a selective marker. Tran- 
Table 1. $\mathrm{IC}_{50}$ values of NT and its related compounds in competition experiments with ${ }^{125} \mathrm{I}$-Tyr ${ }^{3}$-NT on membranes from COS-7 cells transiently transfected with the mNTR, and inhibitory effect of $\mathrm{NA}^{+}$, $\mathrm{K}^{+}$, and $\mathrm{Mg}^{2+}$

\begin{tabular}{llc} 
Compound & Structure & $\begin{array}{c}\mathrm{IC}_{50} \text { values } \\
(\mathrm{nm})\end{array}$ \\
\hline $\mathrm{NT}$ & pELYENKPRRPYIL & $2-3$ \\
$\mathrm{NN}$ & KIPYIL & $1.5-2.5$ \\
Levocabastine & Nonpeptidic & $1-2$ \\
Xenin & MLTKFETKSARVKGLSFHPKRPWIL & $1.5-2$ \\
Trp $^{11}$-NT & pELYENKPRRPWIL & $1-1.5$ \\
D-Trp ${ }^{11}$-NT & pELYENKPRRP[D-Trp]IL & $24-30$ \\
SR48692 & Nonpeptidic & $200-300$ \\
Dynorphin (1-13) & YGGFLRRIRPKLK & $220-300$ \\
NT (1-10) & pELYENKPRRP & $>10,000$ \\
Histamin & Bioamine & $>10,000$ \\
& & \\
Ions & & \\
$\mathrm{Na}^{+}$ & & $250-300$ \\
$\mathrm{~K}^{+}$ & & $300-320$ \\
$\mathrm{Mg}^{2+}$ & & $>100$ \\
\hline
\end{tabular}

The indicated values were obtained from two independent experiments performed in triplicate.

sient transfections were performed with $1 \mu \mathrm{g}$ of recombinant pcDNA3 plasmid by the DEAE-dextran precipitation method (Cullen, 1987) onto semiconfluent COS-7 cells grown in $100 \mathrm{~mm}$ cell culture dishes. Binding and bioassays were performed $\sim 60 \mathrm{hr}$ after transfection. Membranes from nontransfected COS-7 cells were totally devoid of specific ${ }^{125} \mathrm{I}-\mathrm{NT}$ binding.

Binding experiments were carried out on freshly prepared cell membrane homogenates as described previously (Chabry et al., 1994). Cell membranes $(25 \mu \mathrm{g})$ were incubated in $250 \mu \mathrm{l}$ of $50 \mathrm{~mm}$ Tris- $\mathrm{HCl}, \mathrm{pH} 7.5$, containing $0.1 \%$ bovine serum albumin and $0.8 \mathrm{~mm} 1-10$ phenanthroline (binding buffer) with increasing concentrations of ${ }^{125} \mathrm{I}_{-} \mathrm{Tyr}^{3}-\mathrm{NT}$ alone (from 25 to $800 \mathrm{pM}$ ) or isotopically diluted by unlabeled NT (from 0.2 to $20 \mathrm{nM}$ ) for saturation experiments. Nonspecific binding was determined in parallel incubations containing $1 \mu \mathrm{M}$ unlabeled NT. After $20 \mathrm{~min}$ at $25^{\circ} \mathrm{C}$, incubation media were filtered through cellulose acetate filters (Sartorius, Bohemia, NY). Filters were rinsed twice with $2 \mathrm{ml}$ of ice-cold binding buffer and counted in a Packard $\gamma$ counter. Binding parameters [dissociation constant $\left(K_{\mathrm{D}}\right)$ and maximal binding capacity $\left.\left(B_{\max }\right)\right]$ were derived from Scatchard analysis of the data. Competition experiments were

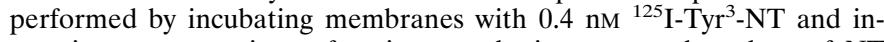
creasing concentrations of various synthetic or natural analogs of NT (from $10^{-11}$ to $10^{-6} \mathrm{M}$ ) or with levocabastine or the nonpeptide NT antagonist SR48692. Incubations were terminated as for saturation experiments. $\mathrm{IC}_{50}$ values were determined from inhibition curves as the unlabeled ligand concentration inhibiting $50 \%$ of ${ }^{125} \mathrm{I}^{-\mathrm{Tyr}^{3}-\mathrm{NT}}$ specific binding.

$R N A$ blot hybridization analysis. RNAs were isolated from different tissues of adult male mice or from whole brain of 7-, 15-, and 35-d-old mice and rats by the guanidinium thiocyanate-phenol-chloroform method (Chomczynski and Sacchi, 1987). Northern analysis was carried out using $10 \mu \mathrm{g}$ of oligo-dT purified poly $\left(\mathrm{A}^{+}\right)$RNAs. The rat cDNA probe used was the $1.27 \mathrm{~kb}$ fragment corresponding to the total reading frame of the NTRH; the mouse cDNA probe used was the $800 \mathrm{bp} \mathrm{BstXI}$ fragment of the NTRL inserted into the pcDNA3 vector.

Electrophysiological measurements. The pcDNA3 vector containing the cDNA of the mouse NTRL served as template to prepare cRNAs using the in vitro transcription kit from Stratagene. cRNAs $(\sim 10 \mathrm{ng})$ were injected into Xenopus laevis oocytes. The oocytes were then incubated at $18^{\circ} \mathrm{C}$ for 2-4 d. Electrophysiological measurements were performed at $20^{\circ} \mathrm{C}$ according to the procedure described previously (Masu et al., 1987). Drugs were applied rapidly into the experimental chamber by a puffer pipette $(200 \mu \mathrm{l})$. Responses to NT, NN, xenin, and levocabastine were recorded under voltage clamp at $-60 \mathrm{mV}$.

In situ hybridization in mouse brain. A 600 bp cDNA fragment corresponding to nucleotides $660-1260$ was inserted into the TA cloning vector
(Invitrogen) by PCR and standard cloning techniques and used as a template to produce sense and antisense ${ }^{33} \mathrm{P}$-labeled RNA probes. Paraformaldehyde-perfused mouse brain sagittal sections were incubated in $120 \mathrm{~mm}$ phosphate buffer, $\mathrm{pH} 7.2$, containing $50 \%$ formamide, $4 \times \mathrm{SSC}$, $1 \times$ Denhardt's solution, $10 \%$ dextran sulfate, and $0.6 \%$ sarcosyl with antisense and sense ${ }^{33} \mathrm{P}$-labeled RNA probes $\left(3 \times 10^{5} \mathrm{cpm} /\right.$ slice $)$. After $15 \mathrm{hr}$ at $50^{\circ} \mathrm{C}$, slices were washed twice with $4 \times$ SSC and $1 \times$ SSC at room temperature, treated with RNase A $(5 \mu \mathrm{g} / \mathrm{ml})$ for $5 \mathrm{~min}$ at $37^{\circ} \mathrm{C}$, and finally washed with $0.1 \times$ SSC and dehydrated in graded ethanol before radioautography for $5 \mathrm{~d}$ on Amersham Hyperfilm $\beta$ max.

\section{RESULTS \\ Molecular cloning and nucleotide and amino acid sequence of the mouse NTR}

A mouse brain cDNA library consisting of $5 \times 10^{5}$ clones was screened by hybridization with a cDNA probe corresponding to the open reading frame of the rat NTRH cDNA clone under low-stringency conditions. The only hybridization-positive clone was then purified. Sequence analysis revealed nucleic acid stretches that shared up to $70 \%$ homology with the rat NTRH cDNA.

Figure 1 shows the 1554 nucleotide sequence determined for the cloned cDNA. The amino acid sequence of the mouse NTRL was assigned from the longest open reading frame of the cDNA. The nucleotide sequence surrounding the putative initiation codon agrees with the consensus sequence for the eukaryotic translation sites (Kozak, 1987). The deduced NTRL sequence consists of 417 amino acid residues with a molecular weight of 46,509 .

The structure of NTRL indicates that it belongs to the large family of G-protein-coupled receptors (Probst et al., 1992), with some peculiarities. The hydropathicity profile analysis (Kyte and Doolittle, 1982) of NTRL is compatible with the possible existence of seven hydrophobic amino acid domains (data not shown). The third intracellular loop and the C-terminal region of NTRL bear many serine (Ser) and threonine (Thr) residues that could serve as possible phosphorylation sites. Moreover, these regions contain several protein kinase $\mathrm{C}$ and casein kinase II consensus sequences (Fig. 1); however, the N-terminal region of NTRL is devoid of potential $\mathrm{N}$-glycosylation sites. This singularity is also observed in the case of the human $\alpha 2-\mathrm{C} 2$ adrenergic receptor (Lomasney et al., 1990). Except for this last point, amino acids that are conserved in most members of the G-protein-coupled receptors are present at the corresponding position in NTRL (Baldwin, 1993).

NTRL shows a high degree of sequence homology with the rat and human NTRH, as illustrated in Figure 2. The global amino acid homology is $39 \%$ and $36 \%$ with the rat and human NTRH, respectively. At the level of the transmembrane domains, however, this homology can rise up to $67 \%$ in TM III and $76 \%$ in TM VII with the rat NTRH. The first and third extracellular loops also show high degrees of sequence homology with the rat NTRH (68 and $59 \%$, respectively). By contrast, the third intracellular loop is 19 amino acids longer than and weakly homologous to that of NTRH. It is noteworthy that NTRL does not show a high degree of sequence similarity with other G-protein-coupled receptors (Probst et al., 1992). The degree of amino acid sequence homology between the mouse NTRL and the NTRHs cloned previously indicates that NTRL belongs to the NTR family but corresponds to a new type of receptor.

\section{Biochemical properties of the mouse NTRL}

The binding properties of the mouse NTRL were characterized by expression after transient transfection of the cloned cDNA in 
Met Glu Thr Ser Ser Leu Trp Pro Pro Arg Pro Ser Pro Ser Ala Gly Leu Ser Leu Glu Ala Arg Leu Gly Val Asp Thr Arg Lel ggagatcaggccaccacgagacagag ATG GAG ACC AGC AGC CTG TGG CCC CCG AGG CCC AGC CCC AGT GCA GGG CTG AGC CTG GAG GCG CGG CTG GGC GTG GAC ACT CGC CTC I

Trp Ala Lys Val Leu Phe Thr Ala Leu Tyr Ser Leu Ile Phe Ala Leu Gly Thr Ala Gly Asn Ala Leu Ser Val His Val Val Leu Lys Ala Arg Thr Gly Arg Pro Trp Ala Lys val Leu Phe Thr Ala Leu Tyr Ser Leu Ile Phe Ala Leu Gly Thr Ala Giy Asn Ala Leu Ser val His val val leu Lys Ala Arg Thr Gly Arg Pro
TGG GCC AAG GTG CTG TTC ACC GCG CTC TAT TCG CTC ATC TTC GCG CTT GGC ACA GCC GGC AAT GCG CTG TCC GTG CAC GTG GTG CTG AAG GCG CGG ACG GGT CGC CCC II

Gly Arg Leu Arg Tyr His Val Leu Ser Leu Ala Leu Ser Ala Leu Leu Leu Leu Leu Ile Ser Val pro Met Glu Leu Tyr Asn Phe Val Trp Ser His Tyr pro Trp GGG CGC CTG CGC TAC CAC GTG CTC AGC CTG GCA CTG TCA GCC CTG CTG CTA CTG CTG ATC AGC GTG CCC ATG GAG CTC TAC AAC TTC GTG TGG TCC CAC TAC CCC TGG III

Val Phe Gly Asp Leu Gly Cys Arg Gly Tyr Tyr Phe Val Arg Glu Leu Cys Ala Tyr Ala Thr Val Leu Ser Val Ala Ser Leu Ser Ala Glu Arg Cys Leu Ala Val GTC TTC GGC GAT CTC GGC TGT CGT GGC TAT TAC T"TC GTG CGC GAG CTG TGC GCC TAC GCC ACG GTG CTG AGC GTG GCC AGC CTG AGC GCA GAG CGC TGC CTG GCC GTG IV

Cys Gln Pro Leu Arg Ala Arg Arg Lel Leu Thr Pro Arg Arg Thr Cys Arg Leu Leu Ser Leu Val Trp Val Ala Ser Leu Gly Leu Ala Leu Pro Met Ala Val Ile 173 TGC CAG CCG CTG CGC GCC CGC CGC CTG CTC ACC CCG CGC CGC ACC TGC CGC CTG CTG TCA CTG GTC TGG GTC GCC TCT CTG GGC CTT GCC CTG CCC ATG GCG GTI ATC 545

Met Gly Gln Lys His Glu Met Glu Arg Ala Asp Gly Glu Pro Glu Fro Ala Ser Arg Val Cys Thr Val Leu val Ser Arg Ala Ser Ser Arg Ser Thr Phe Gln Val 209 ATG GGA CAG AAG CAC GAA ATG GAG AGG GCC GAC GGG GAG CCT GAG CCT GCC TCG CGT GTG TGC ACG GTG CTA GTA AGT CGC GCC AGC TCC AGG TCT ACA TTC CAG GTG 653 $\mathbf{V}$

Iys Arg Ala Gly Leu LeL Arg Ser Pro Leu Tro Glu Leu Thr Ala Ile Leu Asn Gly Ile Thr Val Asn His Leu Val Ala Leu Tyr Ser Gln Val Pro Ser Ala Ser Lys Arg Ala Gly Leu Leu Arg Ser Pro Leu Trp Glu Leu Thr Ala Ile Leu Asn Gly Ile Thr val Asn fis Leu val Ala Leu Tyr Ser Gln val Pro Ser Ala Ser
AAA CGT GCT GGT CTC CTT CGT TCT CCC CTT TGG GAA CTC ACT GCT ATT CTG AAT GGG ATC ACT GTC AAC CAC CTG GTG GCC CTC TAC TCC CAG GTA CCA TCA GCT TCT

*

Ala Gln Val Asn Ser Ile Pro Ser Arg Leu Glu Leu Leu Ser Glu Glu Gly Leu Leu Gly phe Ile Thr Trp Arg Lys Thr Leu Ser Leu Gly Val Gin Ala Ser Leu GCC CAA GTC AAC TCC ATC CCC AGC CGC CTG GAG CTC CTG AGT GAG GAA GGC CTC CTG GGC ITC ATC ACA TGG AGA AAG ACC CTC TCC CTG GGG GTC CAA GCC AGC CTG VI

Val Arg His Lys Asp Ala Ser Gln Ile Arg Ser Leu Gln His Ser Ala Gln Val Leu Arg Ala Ile Val Ala Val Tyr Val tle Cys Tro Leu Fro Tyr His Ala Arg GTG AGA CAC AAG GAT GCC AGC CAG ATC CGC AGC CTC CAG CAC AGC GCC CAG GTT CTC AGA GCC ATC GTG GCT GTG TAT GTC ATC TGC TGG CTG CCG TAC CAT GCC CGC VII

Arg Leu Met Tyr Cys Tyr Ile Pro Asp Asp Gly Trp Thr Asp Glu Leu Tyr Asp Phe Tyr His Tyr Phe Tyr Met Val Thr Asn Thr Leu Phe Tyr Val Ser Ser Ala 353 AGG CTC ATG TAC TGC TAC ATC CCC GAT GAT GGA TGG ACT GAT GAG CTC TAT GAC TTC TAT CAC TAT TTC TAC ATG GTG ACC AAC ACG CTC TTC TAT GTC AGC TCG GCA 1085 Val Thr Pro Val Leu Tyr Asn Ala val ser ser ser phe Arg Lys Leu Phe Leu Glu Ser Leu Ser Ser Leu Cys Gly Glu Gln Arg Ser Val Val pro Leu Pro Gln 389 GTG ACC CCA GTC CTC TAC AAT GCC GTG TCT TCC TCC TTC AGA AAG CTC TTT CTG GAA TCT CTC AGT TCC CTG TGT GGT GAA CAG CGC TCC GTG GTG CCC TTA CCC CAA 1193

Glu Ala pro Glu Ser Thr Thr ser Thr Tyr Ser phe Arg Leu Trp Gly *er Pro Arg Asn Pro Ser Leu Gly Glu Ile Gln Val GAA GCC CCA GAG TCA ACT ACT AGT ACG TAC AGT TTC CGG CTT TGG GGA TCC CCA AGA AAC CCC AGC CTG GGT GAA ATA CAA GIG TGA agagaacaaeaatggctgcttgggaca 1308

cacccatcagataagccatgccattactaacagtctaagcggacctactgacccagcgcagtcattgaccagtgcatactgcaggcaagccacgtaacacctcctgccctcagcttcccacctgtgcaaccaaggtgtagaata 1452

Figure 1. The cDNA sequence of the mouse NTRL and its deduced amino acid sequence. The amino acid sequence deduced for the NTRL is shown above the nucleotide sequence. Positions of the putative transmembrane domains I-VII of the NTRL are indicated above the amino acid sequence on the basis of hydropathicity profile (Kyte and Doolittle, 1982). These segments are marked as stretches of 18 consecutive residues, taking into account the possibility of adding four more residues on each side of the segments (Baldwin et al., 1993). Asterisks and black diamonds indicate potential phosphorylation sites by protein kinase $\mathrm{C}$ and casein kinase II, respectively.

eukaryotic COS-7 cells. ${ }^{125}$ I-Tyr $^{3}$-NT bound to membranes prepared from cells transfected with the NTRL cDNA in a specific and saturable manner (Fig. 3). No binding was detected with membranes prepared from untransfected cells or cells transfected with the vector alone (data not shown). Scatchard plot analysis of ${ }^{125} \mathrm{I}_{-} \mathrm{Tyr}^{3}$-NT binding (Fig. 3, inset) showed a single class of sites with a $K_{\mathrm{d}}$ value of $2.45 \pm 1.04 \mathrm{~nm}(n=6)$. This value is very close to that reported for the low-affinity NT binding site in the brain of mammals (Vincent, 1995).

The ability of various unlabeled peptide and nonpeptide compounds to inhibit the binding of ${ }^{125} \mathrm{I}_{-} \mathrm{Tyr}^{3}$-NT to membranes from COS-7 cells transfected with NTRL is shown in Figure 4 and Table 1. With an $\mathrm{IC}_{50}$ of $1-2 \mathrm{nM}$, the antihistaminic drug levocabastine was as potent as unlabeled NT in inhibiting the binding of labeled NT (Fig. 4). By contrast, histamine lacked the ability to compete for binding to NTRL (Table 1). NN, Trp ${ }^{11}$-NT, and the mammalian xenopsin analog xenin (Feurle et al., 1992) had potencies comparable to that of NT, whereas D-Trp ${ }^{11}$-NT exhibited an $\mathrm{IC}_{50}$ value of $25 \mathrm{nM}$. NT (1-10) was totally devoid of NT binding activity, and dynorphin (1-13), which binds to the levocabastine-sensitive NT binding site in rat brain (Pettibone et al., 1988), inhibited ${ }^{125} \mathrm{I}_{-} \mathrm{Tyr}^{3}-\mathrm{NT}$ binding to NTRL with an $\mathrm{IC}_{50}$ of 200-300 nM. The nonpeptide antagonist SR48692 had an $\mathrm{IC}_{50}$ value of $300 \mathrm{nM}$. We also measured the effect of cations on ${ }^{125} \mathrm{I}_{-\mathrm{Tyr}}{ }^{3}-\mathrm{NT}$ binding and observed that $\mathrm{Na}^{+}$and $\mathrm{K}^{+}$ inhibited the binding with $\mathrm{IC}_{50}$ values of 250 and $300 \mathrm{~mm}$, respectively, whereas $\mathrm{Mg}^{2+}$ at concentrations up to $100 \mathrm{~mm}$ had no effect on NT binding (Table 1). Altogether, these data strongly support the assumption that the newly cloned NT receptor corresponds to the low-affinity, levocabastine-sensitive binding site described previously in rat and mouse brain.

\section{Functional properties of the mouse NTRL}

To investigate the functional properties of NTRL, we expressed this receptor type into Xenopus laevis oocytes. Figure $5 A$ shows examples of electrophysiological responses recorded after application of NT, NN, xenin, and levocabastine to oocytes injected with cRNAs encoding the receptor. The application of $10^{-7} \mathrm{M}$ xenin, $\mathrm{NT}$, or NN induced a $\mathrm{Ca}^{2+}$-activated $\mathrm{Cl}^{-}$current recorded under voltage clamp at $-60 \mathrm{mV}$. The response was greater for NN than for NT itself. The response to $10^{-7} \mathrm{M}$ dynorphin (1-13) was very weak, whereas levocabastine induced a current similar to that evoked by NT. The time necessary to recover the total response was rapid, because applications could be repeated every $20 \mathrm{~min}$ without loss of efficiency, as can be seen with the second application of NN. When $\mathrm{NN}$ was applied again 5 min later (third application), however, a markedly reduced response was recorded (19 $\pm 6 \%$ of the first response; $n=6 ; p=0.007)$. We observed that the period of desensitization varied for each oocyte. In Figure 


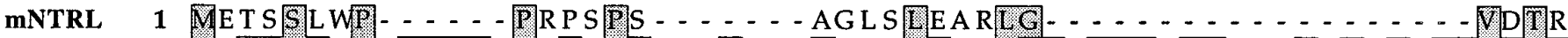

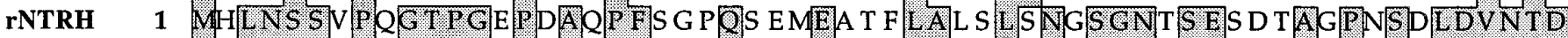
hNTRH 1 MRLNS SAP-GT PGTPAADP FQRAQRAG LEE LLA PGFGNASGNAS ERV LAAPSSELDVNTD

TM I

TM II

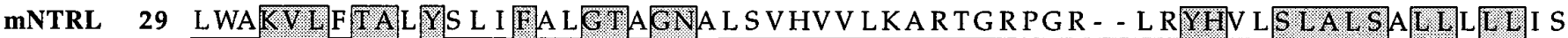

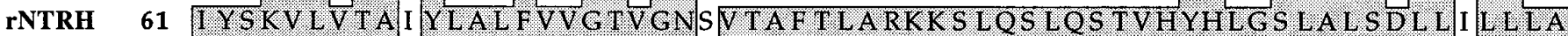

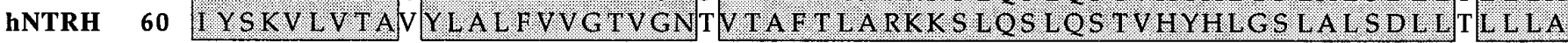

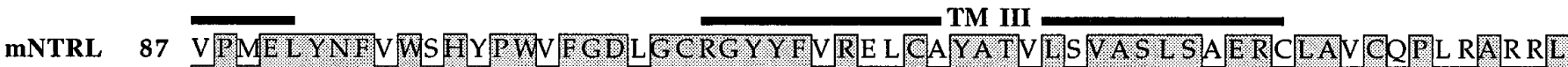

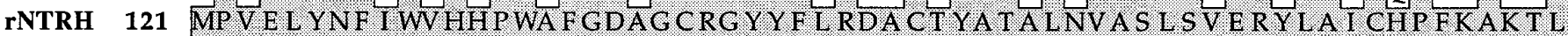

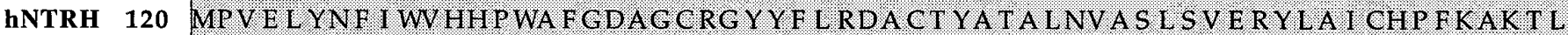

TM IV

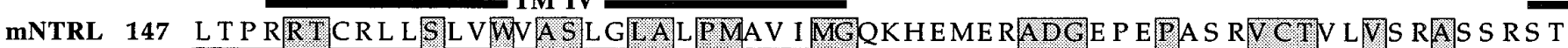

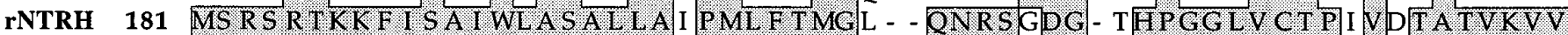
hNTRH 180 MSR S R T KK F I SA I WL A S A L LTVPML F T MGE - - QNR S ADG- QHAGG LV CT PT I HTATVKVV

\begin{abstract}
TM V

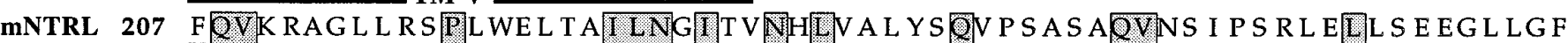

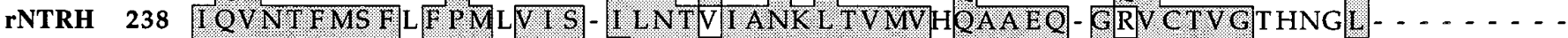

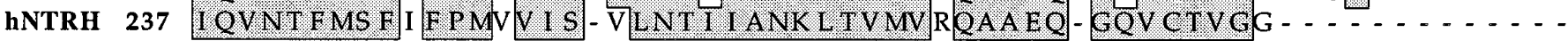

TM VI

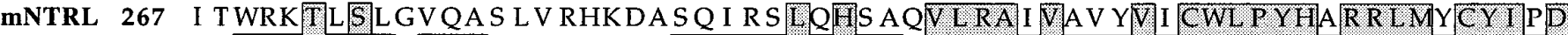
rNTRH $287 \ldots$ EHS T FNMTI EP - . . - - GRVOA R RHGVLV L RA VV T A FV V CWLP Y HV R R LMFCY I SD

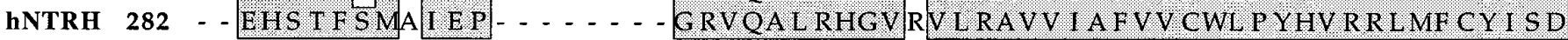

TM VII

MNTRL 327 DGWTD EL YD F YHY F YMV T NT L F YV S S AV TPV L Y NAV S S S F RK LF LE S LS S L CG EQRS VV P

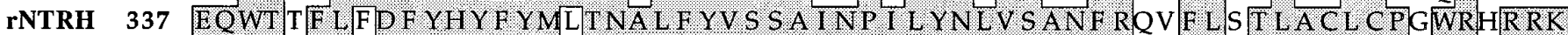
hNTRH 332 EOWTPF L YDF YHY F Y MV T NA L F YV S STTI NP I L Y NL V S A NF RH I F LAIT L A C L C PVWRRR RK

mNTRL 387 - LPQEAPES T T S T YS F R LWG SP RNP S I E E I QV rNTRH 397 KR P T F S RKIP NSTMS S NITA F STTS A T R E T L Y - . hNTRH 392 - R P AF S RK A D V S S NITT L S S NA T R E T L Y. - -

Figure 2. Alignment of the amino acid sequences between mouse, human, and rat NTR. The mouse NTRL $(m N T R L)$ sequence is compared with the rat $(r N T R H)$ (Tanaka et al., 1990) and the human $(h N T R H)$ (Vita et al., 1993) NTRH. The boxed amino acid residues represent residues that are identical The global sequence homology is 39 and $36 \%$ with the rat and the human NTRH, respectively. Positions of the putative transmembrane segments I-VII of the NTRs are indicated.

$5 B$, an example is given in which a second application of NT or $\mathrm{NN}$ after washing for 20 min showed a reduced current amplitude, indicating a desensitization phenomenon. The same oocyte recorded after $5 \mathrm{hr}$ of washing gave a better response to $\mathrm{NN}$ than to NT but was also desensitized. We determined that noninjected oocytes or oocytes injected with antisense mouse NTRL cRNAs were unable to respond to applications of the compounds tested above (data not shown). It is important to note that all oocytes injected with cRNAs encoding the NTRL displayed a recorded membrane potential of $-23 \pm 5 \mathrm{mV}(n=12)$, whereas noninjected oocytes or oocytes injected with cRNAs encoding the rat NTRH (Tanaka et al., 1990) presented a membrane potential of $-55 \pm 6 \mathrm{mV}(n=12)$. The $\mathrm{Cl}^{-}$equilibrium potential of $-20 \mathrm{mV}$ may indicate that NTRL elicits a basal $\mathrm{Ca}^{2+}$ release that activates the $\mathrm{Ca}^{2+}$-dependent $\mathrm{Cl}^{-}$current in the absence of agonist.

\section{Tissue distribution and ontogeny in the brain of NTRL MRNA}

The level of expression of NTRL mRNA in brain and peripheral tissues was examined by blot hybridization analysis. As shown in
Figure $6 A$, mouse poly $\left(\mathrm{A}^{+}\right)$RNAs isolated from the brain and the cerebellum were labeled on a single band with an estimated mRNA size of $\sim 1.8$ kilonucleotides. Note that NTRL expression was slightly higher in the cerebellum. Surprisingly, no labeling of poly $\left(\mathrm{A}^{+}\right)$RNAs isolated from large intestine, heart, testis, and liver was observed under the hybridization conditions used.

To identify definitely the cloned mouse NTRL as the lowaffinity binding site characterized previously in rat and mouse brain, the cerebral expression of the NTRL mRNA at different ages was analyzed and compared with the cerebral expression of the rat NTRH at corresponding ages by blot hybridization. Figure $6 B$ demonstrates that the mouse NTRL was poorly expressed in 7-d-old brain and that the expression increased at day 15 to reach a maximal level in 35-d-old brain. By contrast, the rat NTRH was expressed maximally in 7-d-old brain, and its expression decreased progressively until adulthood (35-d-old brain). These results are totally in accordance with results obtained in binding experiments with rat and mouse brain that described the transient high expression of the NTRH between 7 and $10 \mathrm{~d}$ after birth, whereas the 


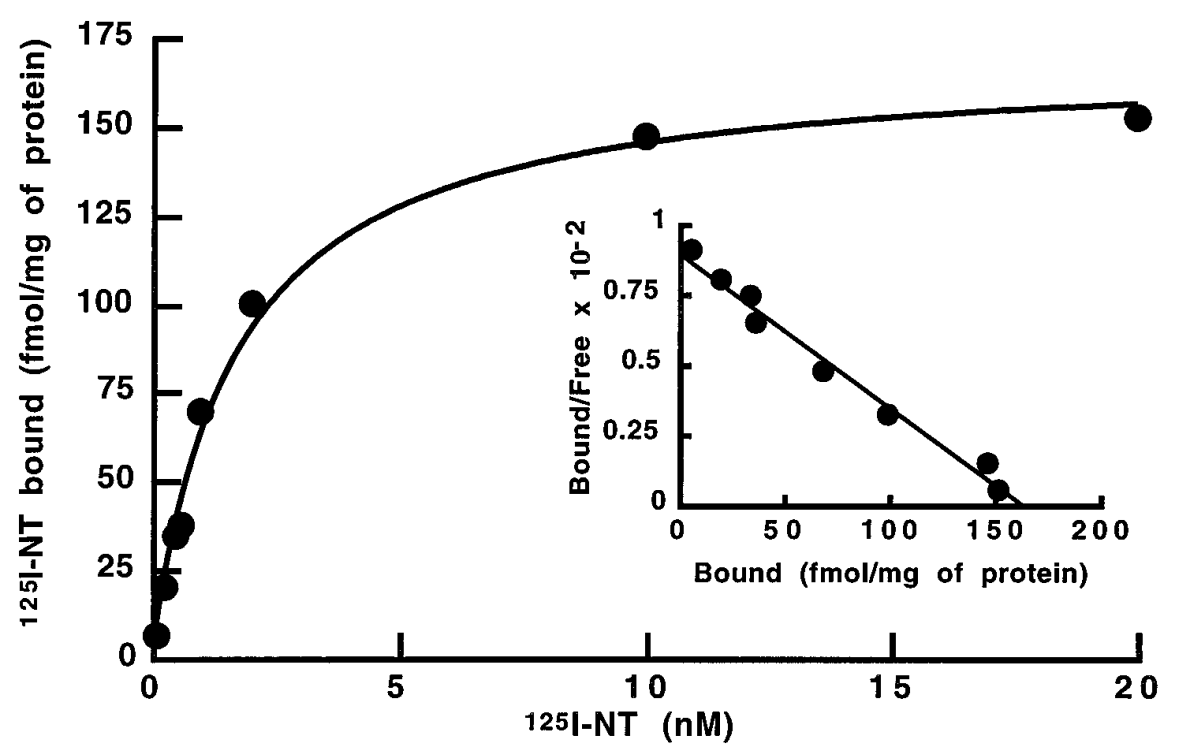

Figure 3. Saturation of specific ${ }^{125} \mathrm{I}_{-} \mathrm{Tyr}^{3}-\mathrm{NT}$ binding to membranes prepared from NTRL cDNAtransfected COS-7 cells. Experimental details are described in Materials and Methods. Results are shown from one of three independent experiments. Inset, Scatchard analysis of the data. In this experiment, $K_{\mathrm{d}}$ and $B_{\max }$ values were $2.2 \mathrm{~nm}$ and 160 $\mathrm{fmol} / \mathrm{mg}$ protein, respectively.
NTRL appeared later and were expressed maximally in adult brain (Schotte and Laduron, 1987; Zsürger et al., 1992).

\section{Distribution of NTRL in the mouse brain}

The regional distribution of this NT receptor type was examined by in situ hybridization analysis. The labeling obtained with the antisense probe is illustrated in Figure $7 A-C$. NTRL mRNAs were expressed in discrete regions of the mouse brain. The most important labeling was observed in the cerebellar cortex, particularly in the layer of Purkinje cells (Fig. $7 A-C$ ). The labeling was also important in the CA1-CA3 fields of the hippocampus, in the dentate gyrus, and at the level of the piriform cortex (Fig. 7B,C). A more diffuse but important labeling was also detected throughout the cerebral neocortex. Note the absence of labeling in the substantia nigra and the hypothalamic regions. A negative control obtained with the sense probe is shown in Figure $7 D$.

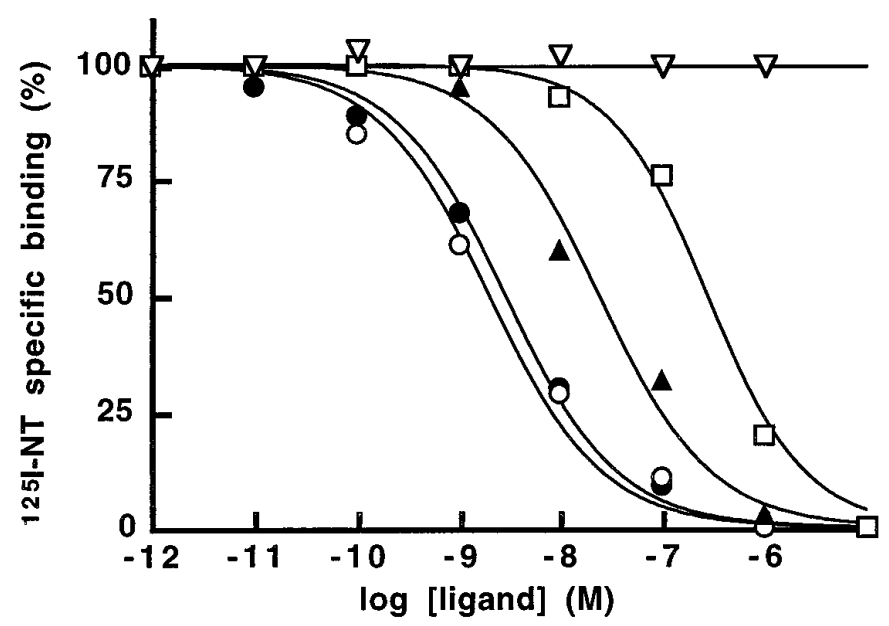

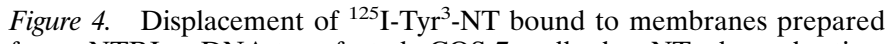
from NTRL cDNA-transfected COS-7 cells by NT, levocabastine, D-Trp ${ }^{11}$-NT, SR48692, and NT (1-10). Experimental details are described in Materials and Methods. The binding of ${ }^{125} \mathrm{I}_{-} \mathrm{Tyr}^{3}$-NT was measured in the presence of increasing concentrations of NT (closed circles), levocabastine (open circles), D-Trp ${ }^{11}$-NT (closed triangles), SR48692, (open squares), and NT (1-10) (open triangles). Each point represents the mean of two separate experiments.

\section{DISCUSSION}

The present study identifies in the mouse brain a NT receptor that shares $39 \%$ and $36 \%$ homology with the previously cloned rat and human NTRH, respectively. Such a relatively low degree of homology makes it likely that the newly cloned receptor is not really the mouse counterpart of the NTRH, but rather represents a new NTR type. Actually, several lines of evidence indicate that the mouse brain receptor characterized here corresponds to the lowaffinity, levocabastine-sensitive NT binding site described previously in the rat and mouse brain (Schotte et al., 1986). Indeed, the pharmacological properties described here for the mouse receptor are comparable to those reported previously for the low-affinity NT binding site. This includes a relatively low affinity (2-3 nM) of NT for the cloned NTRL, the recognition of this receptor type by levocabastine $\left(\mathrm{IC}_{50}=1-2 \mathrm{nM}\right)$, and the fact that the antagonist SR48692 possesses a very low affinity $\left(\mathrm{IC}_{50}=300 \mathrm{nM}\right)$. Furthermore, the sensitivity to cations of the NTRL as described here is similar to that reported for the low-affinity NT binding sites in rat brain (Kitabgi and Vincent, 1986).

The functional consequences of levocabastine binding to NTRL remained unknown until now. The cloning and expression of NTRL in Xenopus leavis oocytes made it possible to address this issue. Interestingly, it was found here that levocabastine behaves as an agonist of the NTRL in the oocyte expression system. It will now be necessary and of interest to investigate further the effects of levocabastine in mammalian systems that express the NTRL, whether normally or on transfection. Because no evidence of coupling to transduction mechanisms has been established for the low-affinity sites, they were considered for a long time as NT acceptor sites devoid of pharmacological function (Laduron, 1995). We now demonstrate that the NT/levocabastine receptor site is a member of the G-protein-coupled receptor family that is coupled functionally to phospholipase $\mathrm{C}$ in the oocyte expression system. Levocabastine could now possibly serve as a specific effector of the NTRL for investigating its central physiological roles. NN, which is produced from a common precursor with NT (Dobner et al., 1987), displays the same affinity as NT on the NTRL, whereas NN is five times less potent than NT on the NTRH (Tanaka et al., 1990). The relatively good affinity of NN for the low-affinity receptor, added to a greater ability to induce 


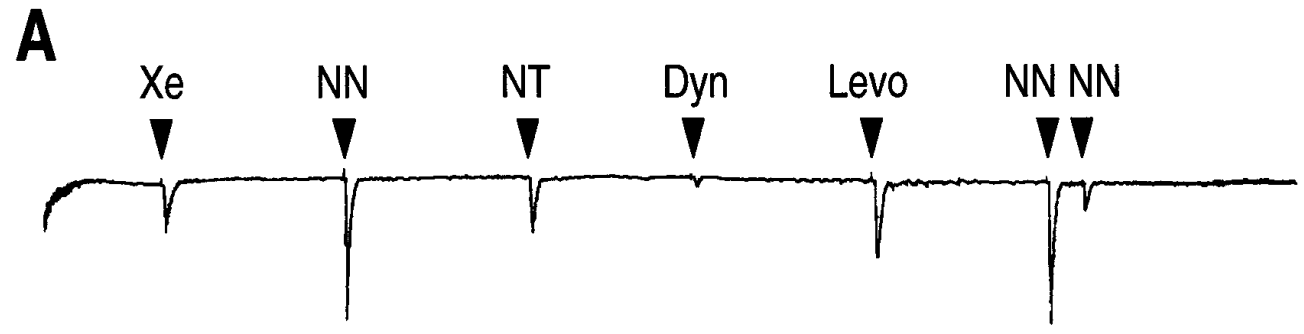

Figure 5. Current traces recorded from Xenopus oocytes injected with the in vitro synthesized NTRL mRNA. Experimental details are described in Materials and Methods. $A, 10^{-7} \mathrm{M}$ xenin $(X e)$, neurotensin $(N T)$, neuromedin $\mathrm{N}(N N)$, dynorphin (1-13) (Dyn), or levocabastine (Levo) was applied every $20 \mathrm{~min} . B$, Applications of $10^{-7} \mathrm{M} \mathrm{NT}$, and then $10^{-7} \mathrm{M} N \mathrm{~N}$, and again $10^{-7} \mathrm{M}$ NT at 20 min time intervals. $C$, The same oocyte as in $B$ was washed for $5 \mathrm{hr}$, and then $10^{-7} \mathrm{M} \mathrm{NN}, 10^{-7} \mathrm{M} \mathrm{NT}$, and $10^{-7} \mathrm{M} \mathrm{NN}$ were applied every $20 \mathrm{~min}$. Downward deflections indicate $\mathrm{Ca}^{2+}$-activated $\mathrm{Cl}^{-}$ currents.
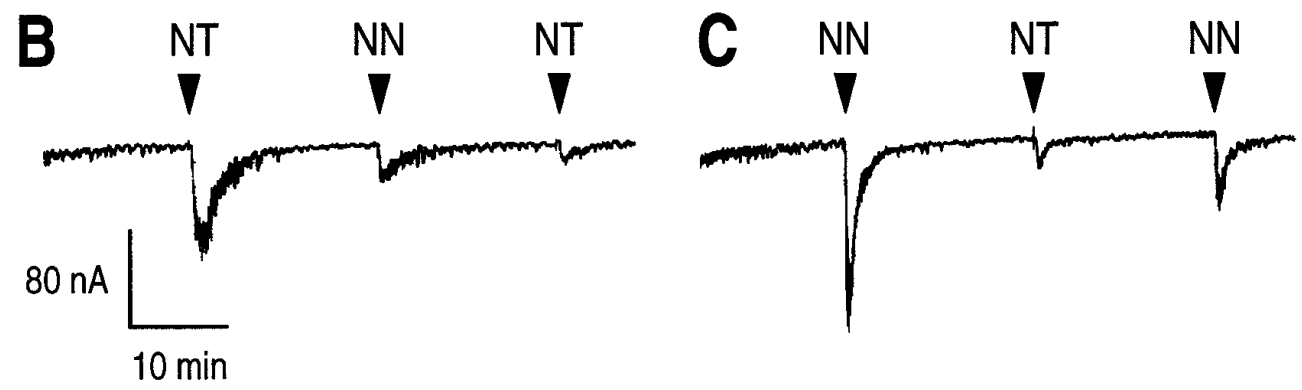

inward currents in the Xenopus laevis oocytes expressing the NTRL, could suggest that this receptor is somewhat specific for NN.

Several additional data identify this newly cloned NTRL as the low-affinity component of NT binding sites. First, the comparison of the cerebral ontogenic expression of the mouse NTRL with the cerebral expression of the NTRH is totally in accordance with the ontogenic expression of the low- and high-affinity NT binding components, respectively, determined in the rat and mouse brain using binding experiments (Schotte and Laduron, 1987; Zsürger et al., 1992). Second, the cerebral pattern of the NTRL expression, particularly in the neocortical region and the CA1 and CA2 fields of the hippocampal formation, has been evidenced previously by radioautography studies performed with ${ }^{125} \mathrm{I}_{-} \mathrm{Tyr}^{3}-\mathrm{NT}$ in the absence or presence of levocabastine (Kitabgi et al., 1987). In the latter study, however, the detection of the levocabastinesensitive NT binding site in CA3 field, dentate gyrus, and piriform

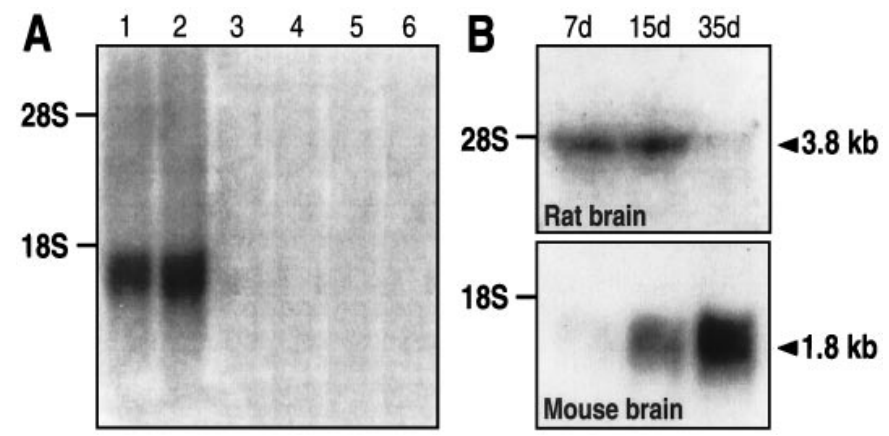

Figure 6. Blot hybridization analysis of poly $\left(\mathrm{A}^{+}\right)$RNAs isolated from various mouse tissues $(A)$ and from rat and mouse brains of different ages $(B)$. Experimental details are described in Materials and Methods. The poly $\left(\mathrm{A}^{+}\right)$RNAs used were isolated from the following tissues: mouse in $A$, lane 1, cerebral cortex; lane 2, cerebellum; lane 3, testis; lane 4, heart; lane 5 , large intestine; and lane 6 , liver; in $B$, whole brain of rat (top) or mouse (bottom) age $7 \mathrm{~d}(7 d), 15 \mathrm{~d}(15 d)$, and $35 \mathrm{~d}(35 d)$. The hybridization was carried out with probes from NTRL in $A$ and $B$ (top) and from NTRH in $B$ (bottom). cortex was not observed. This is probably attributable to the technique used, on the basis of the different labeling obtained with or without levocabastine. Interestingly, the presence of the lowaffinity NT binding component in the cerebellum, particularly in the Purkinje cell layer, has already been observed in a radioautographic study on the ontogeny of rat brain NT receptors, but only $21 \mathrm{~d}$ after birth (Palacios et al., 1988). Overall, the pattern of NTRL expression is clearly distinct from that of NTRH, which is observed mainly in the suprachiasmatic nucleus, supramammillary area, substantia nigra, and ventral tegmental area (Elde et al., 1990), regions that are essentially devoid of NTRL.

Some peculiar structural characteristics of the cloned NTRL need to be emphasized. This receptor clearly belongs to the family of G-protein-coupled receptors, because it possesses seven hydrophobic domains and is coupled in the oocyte expression system; however, the N-terminal sequence of the protein is devoid of a putative N-glycosylation site. This rare property, observed only in the case of the $\alpha 2-c 2$ adrenergic receptor (Lomasney et al., 1990), could explain the relatively low level of expression after transfection into COS-7 cells (100-150 fmol/mg). The other distinct feature corresponds to the absence in TM II of an aspartate (Asp) residue that has been implicated in the $\mathrm{Na}^{+}$sensitivity of other G-protein-coupled receptors such as the somatostatin receptor $2 \mathrm{a}$ (Kong et al., 1993). The lack of Asp residue could be responsible for the low sensitivity of NTRL to $\mathrm{Na}^{+}$ions $\left(\mathrm{IC}_{50}=250 \mathrm{~mm}\right)$. Furthermore, this together with the extremely rich composition in Ser/Thr residues (23 and 6, respectively) of the third intracytoplasmic loop and the $\mathrm{C}$ terminus of the protein might explain its relatively low-affinity state for natural ligand(s). The strong desensitization of the receptor observed in Xenopus oocytes could be related to the presence of these residues rather than being a consequence of a temporary depletion of $\mathrm{Ca}^{2+}$ from intracellular stores. Indeed, the abundance of Ser/Thr residues might play a role in desensitizing the NTRL by allowing the numerous protein kinase $\mathrm{C}$ and casein kinase phosphorylation sites to maintain the receptor protein under a basal phosphorylation state that could desensitize the effector system. A similar mechanism has been 

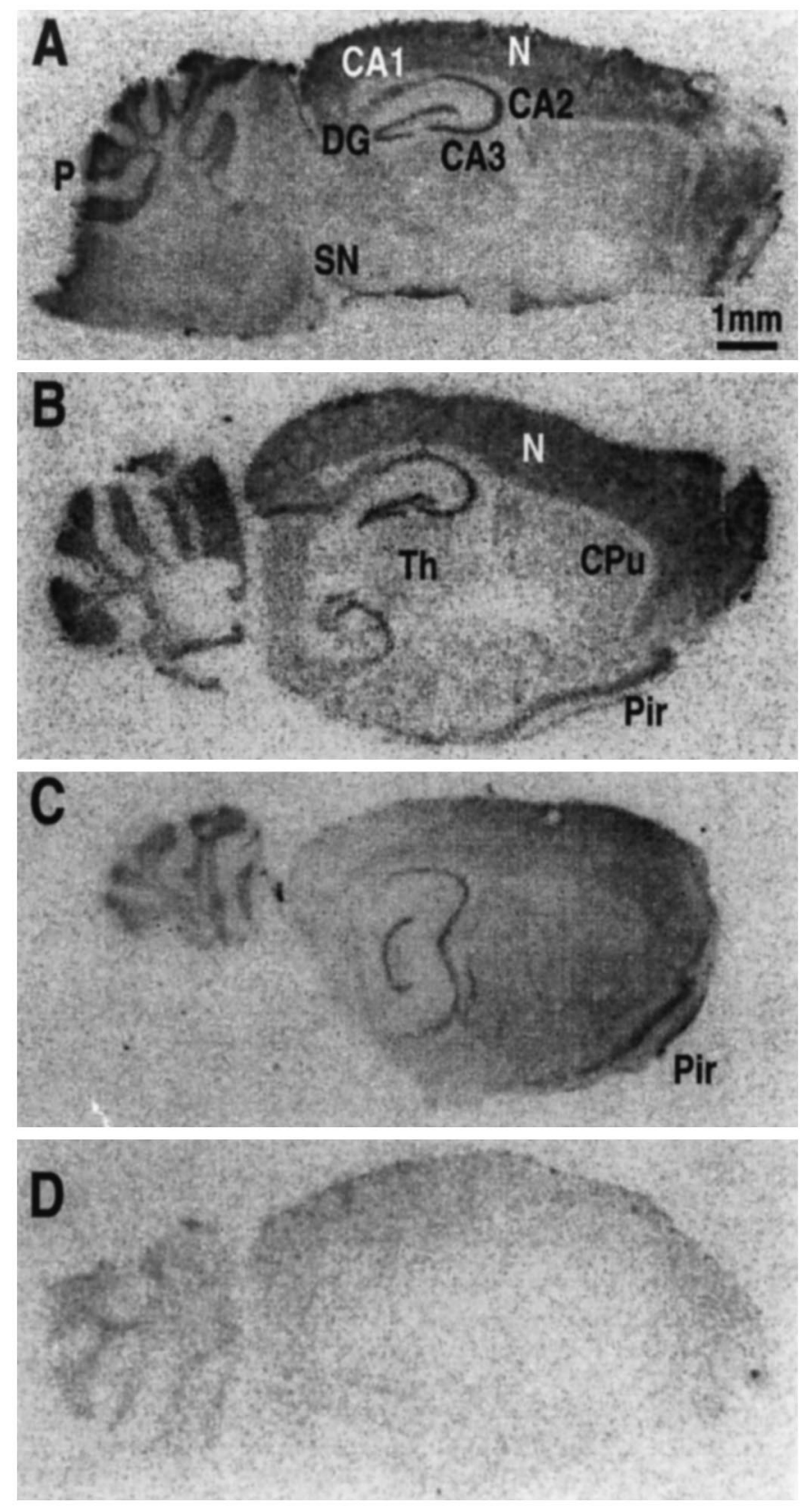

Figure 7. Localization of the NTRL in the mouse brain by in situ hybridization analysis. Experimental details are described in Materials and Methods. Sagittal brain slices were hybridized with the antisense $(A$, L1.45; $B, \mathrm{~L} 2.2 ; C, \mathrm{~L} 2.45)$ or with the sense $(D)$ mNTR probe. $C A 1, C A 2$, $C A 3$, Fields of the hippocampus; $C P u$, caudate putamen; $D G$, dentate gyrus; $P$, Purkinje cell layer; $N$, neocortex; $S N$, substantia nigra; $T h$, thalamus; Pir, piriform cortex. Scale bar, $1 \mathrm{~mm}$.

proposed to explain the high rate of desensitization observed with the NTRH (Tanaka et al., 1990).

The differential tissue distribution of NTRL and NTRH suggests that these receptors might subserve distinct NT effects. Pharmacological data also support this hypothesis. In this context, it is worth noting that the recently developed nonpeptide antagonist SR48692 is much less potent on the new NT receptor $\left(\mathrm{IC}_{50}\right.$ $=300 \mathrm{nM}$ ) than on the rat brain NTRH $\left(\mathrm{IC}_{50}=5.6 \mathrm{nM}\right.$ ) (Gully et al., 1993). The fact that SR48692 failed to antagonize the hypothermic and analgesic effects of intracerebroventricular injections of NT in the mouse and rat (Dubuc et al., 1994) could suggest that the newly cloned NTRL described in this work mediates these effects. Supporting this contention further is the finding that the $\mathrm{D}-\operatorname{Trp}^{11}$-NT analog, which is one of the most potent effectors on hypothermia and analgesia, displays a relatively good affinity for the mouse NTRL $\left(\mathrm{IC}_{50}=25 \mathrm{nM}\right)$ by comparison with its poor affinity for the rat NTRH $\left(\mathrm{IC}_{50}=320 \mathrm{nM}\right.$ ) (Labbé-Jullié et al., 1994). Structure-activity studies with a number of peptide and pseudopeptide NT analogs have revealed clear, distinct pharmacological profiles for the analgesic and hypothermic responses on the one hand and binding to the NTRH on the other hand (Al-Rhodan et al., 1991; Labbé-Jullié et al., 1994). In particular, some analogs were shown to behave as potent agonists of the hypothermic and analgesic responses, whereas they had low affinity for the NTRH. It will be of great interest to assess the binding properties of these analogs on the NTRL. This could provide definitive evidence for a role of the NTRL in mediating the analgesic and hypothermic effects of NT and might open the way for designing potent analgesic compounds devoid of the NT effects exerted through the NTRH. It could also lead to the development of high-affinity ligands specific for the NTRL that could provide useful tools to characterize further the pharmacological properties and cerebral distribution of this new receptor.

In summary, this work demonstrates that at least two different types of functional NT receptors exist. The new NT receptor cDNA described here should help to define more accurately the different pathways leading to the expression of the various central and peripheral properties of NT.

\section{REFERENCES}

Al-Rodhan NRF, Richelson E, Gilbert JA, McCormick DJ, Kanba KS, Pfenning MA, Nelson A, Larson EW, Yaksh TL (1991) Structureantinociceptive activity of neurotensin and some novel analogues in the periaqueductal gray region of the brainstem. Brain Res 557:227-235.

Baldwin JM (1993) The probable arrangement of the helices in G protein-coupled receptors. EMBO J 12:1693-1703.

Chabry J, Labbé-Jullié C, Gully D, Kitabgi P, Vincent JP, Mazella J (1994) Stable expression of the cloned rat brain neurotensin receptor into fibroblasts: binding properties, photoaffinity labeling, transduction mechanisms, and internalization. J Neurochem 63:19-27.

Chomczynski P, Sacchi N (1987) Single-step method of RNA isolation by acid guanidinium-phenol-chloroform extraction. Anal Biochem 162:156-159.

Cullen BR (1987) Use of eukaryotic expression technology in the functional analysis of cloned genes. Methods Enzymol 152:684-695.

Dubuc I, Costentin J, Terranova JP, Barnouin MC, Soubrié P, Le Fur G, Rostène W, Kitabgi P (1994) The nonpeptide neurotensin antagonist, SR 48692, used as a tool to reveal putative neurotensin receptor subtypes. Br J Pharmacol 112:352-354.

Dobner PR, Barber DL, Villa-Komaroff L, McKierman C (1987) Cloning and sequence analysis of cDNA from the canine neurotensin/ neuromedin N precursor. Proc Natl Acad Sci USA 84:3516-3520.

Elde R, Schalling M, Ceccatelli S, Nakanishi S, Hökfelt T (1990) Localization of neuropeptide mRNA in rat brain: initial observations using probes for neurotensin and substance $\mathrm{P}$ receptors. Neurosci Lett 120:134-138.

Feurle GE, Hamscher G, Kusiek R, Meyer HE, Metzger JW (1992) Identification of xenin, a xenopsin-related peptide, in the human gastric mucosa and its effects on exocrine pancreatic secretion. J Biol Chem 267:22305-22309.

Gully D, Canton M, Boigegrain R, Jeanjean F, Molimard JC, Poncelet M, Gueudet C, Heaulme M, Leyris R, Brouard A, Pelaprat D, Labbé-Jullié C, Mazella J, Soubrié P, Maffrand JP, Rostène W, Kitabgi P, Le Fur G (1993) Biochemical and pharmacological profile of a potent and selective nonpeptide antagonist of neurotensin receptor. Proc Natl Acad Sci USA 90:65-69.

Hermans E, Maloteaux JM, Octave JN (1992) Phospholipase C activation by neurotensin and neuromedin $\mathrm{N}$ in chinese hamster ovary cells expressing the rat neurotensin receptor. Mol Brain Res 15:332-338. 
Kitabgi P, Vincent JP (1986) Effects of cations and nucleotides on neurotensin binding to rat brain synaptic membranes. In: Neural and endocrine peptides and receptors (Moody TW, ed), pp 313-319. New York: Plenum.

Kitabgi P, Rostène W, Dussaillant M, Schotte A, Laduron PM, Vincent JP (1987) Two populations of neurotensin binding sites in murine brain: discrimination by the antihistamine levocabastine reveals markedly different radioautographic distribution. Eur J Pharmacol 140:285-293.

Kong H, Raynor K, Yasuda K, Bell GI, Reisine T (1993) Mutation of an aspartate at residue 79 in the SRIF receptor subtype SSTR2 prevents $\mathrm{Na}^{+}$regulation of agonist binding but does not affect apparent receptor/G protein association. Mol Pharmacol 44:380-384.

Kozak M (1987) An analysis of 5'-noncoding sequences from 699 vertebrate messenger RNAs. Nucleic Acids Res 15:8125-8148.

Kyte J, Doolittle RF (1982) A simple method for displaying the hydropathic character of a protein. J Mol Biol 157:105-132.

Labbé-Jullié C, Dubuc I, Brouard A, Doulut S, Bourdel E, Pelaprat D, Mazella J, Martinez J, Rostène W, Costentin J, Kitabgi P (1994) In vivo and in vitro structure-activity studies with peptide and pseudopeptide neurotensin analogs suggest the existence of distinct central neurotensin receptor subtypes. J Pharmacol Exp Ther 268:328-336.

Laduron PM (1995) Functional consequences of retrograde axonal transport of receptor-bound neurotensin. Trends Pharmacol Sci 16:338-343.

Lomasney JW, Lorenz W, Allen LF, King K, Regan JW, Yang FTL, Caron MG, Lefkowitz RJ (1990) Expansion of the alpha 2-adrenergic receptor family: characterization of a human alpha 2-adrenergic receptor gene for which is located on chromosome 2. Proc Natl Acad Sci USA 87:5094-5098.

Masu Y, Nakayama K, Tamaki H, Harada Y, Kuno M, Nakanishi S (1987) cDNA cloning of bovine substance-K receptor through oocyte expression system. Nature 329:836-838.

Mazella J, Poustis C, Labbé C, Checler F, Kitabgi P, Granier C, Van Rietschoten J, Vincent JP (1983) Monoiodo $\operatorname{Trp}^{11}$-neurotensin, a highly radioactive ligand of neurotensin receptors: preparation, biological activity, and binding properties to rat brain synaptic membranes. J Biol Chem 258:3476-3481.
Palacios JM, Pazos A, Dietl MM, Schlumpf M, Lichtensteiger W (1988) The ontogeny of brain neurotensin receptors studied by autoradiography. Neuroscience 25:307-317.

Pettibone DJ, Totaro JA, Harris E, Robinson FM (1988) Heterogeneity of $\left[{ }^{3} \mathrm{H}\right]$ neurotensin binding: studies with dynorphin, L-156,903 and levocabastine. Brain Res 457:212-218.

Probst WC, Snyder LA, Schuster DI, Brosius J, Sealfon SC (1992) Sequence alignment of the G-protein coupled receptor family. DNA Cell Biol 11:1-20.

Sadoul JL, Mazella J, Amar S, Kitabgi P, Vincent JP (1984) Preparation of neurotensin selectively iodinated on the tyrosine 3 residue: biological activity and binding properties on mammalian neurotensin receptors. Biochem Biophys Res Commun 120:812-819.

Sambrook J, Fritsch EF, Maniatis T (1989) Molecular cloning: a laboratory manual. Cold Spring Harbor, NY: Cold Spring Harbor Laboratory.

Schotte A, Laduron P (1987) Different postnatal ontogeny of two $\left[{ }^{3} \mathrm{H}\right]$ neurotensin binding sites in rat brain. Brain Res 408:326-328.

Schotte A, Leysen JE, Laduron PM (1986) Evidence for a displaceable non-specific $\left[{ }^{3} \mathrm{H}\right]$ neurotensin binding site in rat brain. Arch Pharmacol 333:400-405.

Tanaka K, Masu M, Nakanishi S (1990) Structure and functional expression of the cloned rat neurotensin receptor. Neuron 4:847-854.

Vincent JP (1995) Neurotensin receptors: binding properties, transduction pathways, and structure. Cell Mol Neurobiol 15:501-512.

Vita N, Laurent P, Lefort S, Chalon P, Dumont X, Kaghad M, Gully D, Le Fur G, Ferrara P, Caput D (1993) Cloning and expression of a complementary DNA encoding a high affinity human neurotensin receptor. FEBS Lett 317:139-142.

Watson MA, Yamada M, Yamada M, Cusak B, Veverka K, BoldenWatson C, Richelson E (1992) The rat neurotensin receptor expressed in chinese hamster ovary cells mediates the release of inositol phosphates. J Neurochem 59:1967-1970.

Zsürger N, Chabry J, Coquerel A, Vincent JP (1992) Ontogenesis and binding properties of high-affinity neurotensin receptors in human brain. Brain Res 586:303-310. 